\title{
Innovative Methods in Language Disciplines During Profile Training Implementation
}

\author{
Halyna I. Yuzkiv ${ }^{1}$, Iryna M. Ivanenko ${ }^{1}$, Nataliia V. Marchenko², Natalia V. Kosharna ${ }^{3} \&$ Natalia S. Medvid $^{4}$ \\ ${ }^{1}$ Department of Ukrainian Studies, Bogomolets National Medical University, Kyiv, Ukraine \\ ${ }^{2}$ Department of Adult Education, Faculty of Education and Research Management, National Pedagogical \\ Dragomanov University, Kyiv, Ukraine \\ ${ }^{3}$ Foreign Languages and Methodology Department, Pedagogical Institute, Borys Grinchenko Kyiv University, Kyiv, \\ Ukraine \\ ${ }^{4}$ Ukrainian Language, Literature and Teaching Methods Department, Philology and History Faculty, Oleksandr \\ Dovzhenko Hlukhiv National Pedagogical University, Hlukhiv, Ukraine
}

Correspondence: Halyna I. Yuzkiv, Bogomolets National Medical University, 34 Victory Avenue, Kyiv, 01601, Ukraine.

Received: June 10, 2020

Accepted: August 3, 2020

Online Published: August 7, 2020

doi:10.5430/ijhe.v9n7p230

URL: https://doi.org/10.5430/ijhe.v9n7p230

\begin{abstract}
The advanced pedagogical experience testifies to the presence of a number of methods in the practice of teaching language disciplines used by teachers during profile training at school or other educational institutions. With the development of modern information technologies, the role of traditional methods of studying language disciplines in the educational process is changing to the advantage of more innovative (interactive) methods of studying language disciplines. Therefore, the purpose of the article is to investigate the peculiarities of the application of innovative methods in language disciplines during profile training implementation. To achieve the purpose specified, an academic paper uses a number of general scientific (method of theoretical analysis, method of observation, method of description and method of synthesis) and empirical (experimental method, modeling method and calculation method) research methods. The practical reflection of the state and dynamics of mastering language disciplines during profile training is demonstrated through: the efficiency level of the applied innovative methods of studying language disciplines; the dynamics of the average number of students, involved in studying foreign language per student at the level of higher secondary education; rating of the countries of European Union and Ukraine on English proficiency according to the Global rating of countries and regions; provisions of New Ukrainian School Concept. It has been established that in the countries of European Union the practice of studying language disciplines is based on the translation method, the method of meaningful and language integrated learning, the methods of using digital technologies and the method of using creative objects. The study has revealed that such countries of European Union, as Luxembourg, Romania and Finland have significantly high levels of foreign language proficiency; however, such levels of language command are significantly low in Greece, Denmark, Spain, Germany and Portugal. It has been established that Ukraine is classified as a country with a low level of English language command (proficiency) in the Global Ranking of Countries and Regions (according to data of 2019, 2017 and 2016) and a moderate level of English language proficiency (according to data of 2018 and 2015). The following types of innovative methods, currently used by teachers in language disciplines during profile training, have been summarized, namely: the use of information and computer technology in the process of language learning; the use of developmental methods in the form of dialogue, discussion, seminar or brainstorming; construction of the educational process in the form of a game, project, team game; introduction of creative and interactive tasks into the educational process.
\end{abstract}

Keywords: profile training, language disciplines, foreign language, new Ukrainian school concept

\section{Introduction}

The advanced pedagogical (teaching) experience testifies to the presence of a number of methods in the practice of teaching language disciplines used by modern teachers (educators) during profile training at school or other educational establishments (including higher educational institutions). In particular, currently the functional ones are quite common, including the method of oral learning and the method of situational language learning, as well as the 
structuralist methods, among which the grammar-translation method and the audio-language method should be specified. However, as studies show, the role of the above mentioned methods of learning language disciplines in the educational process is changing to the advantage of more innovative (interactive) methods of learning language disciplines due to the development of modern information technology.

At the same time, it should be noted that the profile training is based on the process of determining the abilities and interests of high school students as well as students of higher educational institutions, as this will in the long run provide them with more in-depth training in knowledge-sharing and interest-based knowledge.

Therefore, based on the social importance of study issues of language disciplines, the topic relevance of the scientific paper is aimed at investigation of modern innovative methods used by educators to teach language disciplines during profile training implementation.

The purpose of the investigation is to study and compare the experience of EU countries in terms of using innovative methods in language disciplines during profile training.

\section{Literature Review}

Within this framework, Abduhalykova (2016) in her own research "Innovative Methods of Foreign Languages Teaching" states that innovative methods, in particular, information and computer technologies are used for studying language disciplines and increase the transfer efficiency of knowledge, skills and abilities from teachers to students (pupils, higher education applicants).

Kuzjmychova (2014), in the context of studying innovative approaches (methods) to teaching the Ukrainian language and literature within the conditions of profile education at the modern school, emphasizes the use of various technologies of developmental learning, among which special attention is paid to technologies of problem-based material presentation and communication and dialogue technologies(in particular, training in the form of directed dialogue, discussion, seminar, brainstorming).

Zhalilova (2018) in the study "Implementation of innovative techniques in foreign language teaching" considers one of the most common innovative methods of learning language disciplines nowadays - the method of online grammar games. In this study, the scientist also reveals the efficiency level of using video materials, forasmuch as they constitute a significant impact on improving the performance and acquisition of knowledge by students (higher education applicants) in the context of studying language disciplines.

In turn, Idrisalieva (2019) in the academic paper "Innovative Methods of Teaching Foreign Languages in Non-Philologigal Universities" considers a number of modern innovative methods and techniques, including such as: audiovisual method, audiolinguistic method, communicative method, direct method.) According to the viewpoint of the scientist, the above mentioned methods significantly increase the efficiency level of presenting material by teachers (educators) to students (higher education applicants).

Polonsjka (2014) in methodological recommendations "Profile foreign language teaching of high school students" divides the profile studying of foreign language of high school students into four levels, namely: 1) the first level, which includes a profile course of at least 5 hours per week, with a base course of only 3 hours per week; 2) the second level, which supplements the first level and includes tasks of a detailed studyof the basic course materials (that is, the task of a comprehensive analysis of texts, annotation, abstracting); 3) the third level, which complements the first and the second levels and includes the tasks of additional professional-oriented material and certain activities that are reflected in the modules (for example: studying the content of the"language"concept and the language science, studying the history of development and the literary features of the language; study of features of foreign language's development); 4) the fourth level, based on the results from passing the first, the second and the third levels, provides for conducting elective courses and gaining practical experience. In addition, the scientist considers such innovative methods and techniques of profile training in language disciplines as: the use of mind maps, clusters, diamond, cinquain, collaborative learning, team training, individual and group method of training, individualization of team learning, team-game method of training in a team based on the game, "learning together" method and project method.

Redjko and Pasichnyk (2012) in the investigation "Features of constructing the content of level-based learning foreign languages at high schools of Ukraine" state that the achievement of positive results by students in studying foreign languages in a senior specialized school will be facilitated by the use of such methods in profile education, namely: method of studying problems of communicative activity's organization, method of using interactive and creative tasks, method of language situation, project method. 
At the same time, Rozhkova (2014) in the research article "The use of information and computer technology as an innovative method in teaching foreign languages" concludes that the key innovative method in the study of foreign languages, for example, by senior school students, is the use of information and computer technologies (in particular multimedia technologies, the Internet, computer) in the learning process.

The team of scientists in the investigation "The Importance of Modern Methods and Technologies in Learning English" emphasize the role of innovative technologies, as well as modern information and communication methods, which are extremely necessary for learning foreign languages (Bolibekova, Jalolova, Nematov \& Tangriyev, 2020).

In turn, Jakymenko (2019) in the research "Formation of technological readiness of future foreign language teachers for profile training of high school students by tools of innovative technologies" claims that the outcome of profile education in the context of foreign language learning by senior school students depends on teachers' technological readiness.Herewith, the determining factor in readiness is the use of innovative technologies, including the implementation into the learning process of the UK's experience of using innovative pedagogical technologies, such as: 1) tutoring; 2) language portfolio; 3 ) technologies of context-language learning (immersion learning technologies); 4) direct learning technologies; 5) technologies of language immersion; 6) technologies of individualization and personification of the educational process (in particular suggestion technology); 7) technology of associated symbols; 8) associations technology; 9) technologies of mind maps construction;10) creative and diagnostic technologies.

For instance, under tutoring Bojko (2010) in the research article "Tutoring as a means of meeting the educational needs of the individual, the country and the society" understands the technology of individualization of education, according to which such conditions of involving of higher education applicant (student) into educational process should be formed, which will make it possible to manage this process as personal educational trajectory. This innovative teaching method involves participation of a tutor in the process of studying language disciplines; this is a person who organizes the educational process in accordance with a specially developed educational paradigm.

At the same time, according to the research of Ghorpinich (2015), presented in the academic paper "Language portfolio as a means of self-control in learning a foreign language", such an innovative method as language portfolio is one of the main means of self-control in the context of language learning. Thus, applicants, learning a foreign language, are able to independently check and assess their own achievements. In addition, the knowledge, skills and abilities of the applicant, in relation to the language he has learned, can also be assessed by the teacher. This innovative method is based on a European language portfolio specially developed and tested by Council of Europe. Considering that, the basic subtypes of the language portfolio as one of the most common innovative methods that are used in the context of the studying language disciplines are as follows:

a) language portfolio as a way of autonomous study of language disciplines;

b) language portfolio as a way of self-assessment of the applicant's achievements in the context of learning a foreign language (language disciplines);

c) language portfolio as a way to demonstrate the educational product, that is, the result of mastering the foreign language by the applicant;

d) multi-purpose language portfolio, which characterizes a number of outlined goals in the process of learning a foreign language (language disciplines);

e) language portfolio as a way to achieve feedback in the learning process.

With regard to the technologies of contextual language learning, according to the research of Kozhukhar and Matviienko (2020), presented in "Technologies of contextual learning of a foreign language in the professional development of the future specialist", this innovative method, which is applied to study language disciplines, should be understood as one of the key tools of modeling the applicant's professional activity in prospect. In addition, the use of such a method makes it possible to increase the activity of applicants to acquire knowledge, which, in turn, will contribute to the formation of future professionals' personal qualities.

According to the studies of Hodovanets (2014), presented in the research article "Application of the direct method in learning a foreign language", the essence of the direct method of learning (in other words, the method of direct learning technologies) is laid in the following aspects: 1) learning begins with dialogues that are created on a modern conversational style; 2) studying grammar and language is carried out on an inductive basis; 3) the use of the native language is not required in the context of learning a foreign language, consequently, the teacher is not obliged to speak the native language of the applicants; 4) the teacher should be a native speaker, have a natural pronunciation 
and practical communication skills; 5) it is assumed to use visual aids and conduct specific actions for visual study of a foreign language.

A key feature of the application of language immersion technologies according to the research of Vyselko (2012), submitted in "Ways to introduce foreign language immersion in learning English for professional purposes", is aimed at: 1) improving the level of foreign language proficiency; it provides the use of this learning method only when the level of foreign language proficiency of applicants is not below average; 2) introduction of this learning method to applicants (students) of the last courses of training, forasmuch as then the training is based on the content that is preceded by the language course; 3 ) application of this learning technology for learning a foreign language by both students of specialized language disciplines and students of non-language disciplines.

Kostolanyova and Nedbalova (2017), based on the results of the implementation of individualization and personification technologies in the educational process, have come to the conclusion that the educational process needs to be set up in the context of using various information and communication technologies. Moreover, individualization as a learning technology, according to investigations of scholars, is a method of differentiation of learning, where there must be constant progress in learning. At the same time, scientists understand personalization as a method of teaching, according to which the role of the teacher in the educational process is aimed at providing pieces of advice to the applicant (student), as well as the motivation of applicants (students) to study.

However, Liu and Shi (2007) in the study "An Analysis of Language Teaching Approaches and Methods Effectiveness and Weakness" highlight a number of teaching approaches and methods used for language teaching. In this connection, scholars contend these are grammatical methods of translation, methods of transition from a literary language in everyday colloquial speech, an audio-lingual method and a communicative method.

While studying the formation process's featuresof professionally significant qualities of future teachers of language disciplines (foreign languages) Kotenko (2012) notes a number of factors influencing this process. Consequently, these are the intrinsic features of the future teachers'development, in particular: age, practical and life experience, individual beliefs, and the external influence of world and social trends on the professional training of future teachers.

In addition, Carless (2012) in the scientific investigation "Innovation in Language Teaching and Learning" examines the basic obstacles that arise in the application of innovative methods of learning language disciplines. Thus, according to the scientist's viewpoint, it is as follows: 1) misunderstanding by the teacher (educator) of the content of innovations; 2) lack of mutual trust between the teacher (educator) and students (higher education applicants); 3 ) conservative approach to the educational process.

Vega (2018) in the investigation "An Analysis of the Most Common Methods Used to Teach English as a Second and Foreign Language" considers the following methods of studying language disciplines that are the most common nowadays, namely: 1) the method of translation and grammar; 2) a direct method; 3) an audiolinguistic method; 4) the method of natural approach.

Alimova (2018) in the research article "Innovative approaches in the technique of teaching foreign languages" explores the features of the creative method of learning a foreign language, which is based on special goals (Languages for Special Purposes). Thus, in practice, the application of this method of learning a foreign language is carried out in a specially created artificial environment of professionals.

Furthermore, Kotenko and Holovatenko (2020) represent the model of higher education that should be acquired by future teachers of language disciplines (foreign languages), based on the study of European legislation concerning provision training for teachers. The model submitted by scientists is based on the results of a binary model developed on the example of studying the experience of teachers' training in Belgium. In addition, scientists have investigated the features of teachers' training in Luxembourg, Germany, France and the Czech Republic, using parallel and sequential models. Based on the results of the research conductedand in the context of their interpretation on Ukraine's practice of teachers' training, scientists have come to the conclusion that the higher education system of Ukraine is characterized by a binary model, where teachers' training is carried out according to comprehensive and specialized directions.

At the same time, Palamar, Vaskivska and Porjadchenko (2019) emphasize the importance of dialogic communication as a means of creating a culture of communication among future teachers. The use of dialogic communication on a practical level of teachers' training will encourage them to self-determination in the process of communication, gaining new knowledge, skills and abilities, as well as experience how to behave in unexpected and unusual situations. 


\section{Data and Methods}

To achieve the purpose specified, the academic paper uses a number of general scientific and empirical research methods. In particular, the analysis, observation, description have been used to reveal the theoretical and methodological features of the introduction of innovative methods in the practice of studying language disciplines. The practical results of the study are reflected through the use of such methods, as: experimental method, modeling method and calculation method.

The practical reflection of the state and mastery dynamics of language disciplines (foreign languages) during profile training implementation is demonstrated through:

- the efficiency level of the applied innovative methods in learning language disciplines;

- the dynamics of the average number of foreign languages studied per student by the level of senior secondary education (to study the state and mastery level of foreign languages in the countries of European Union);

- rating of the countries of European Union and Ukraine on command of English according to the Global ranking of countries and regions (EF Education First, 2020);

- provisions of the New Ukrainian School Concept.

The study analyzed the following indicators:

1. Average number of foreign languages studied per pupil (student) by the level of senior secondary education in 2015, 2017.

2. Rating of the countries of the European Union and Ukraine on English language proficiency according to the Global Ranking of Countries and Regions in 2015-2019.

\section{Results of the Study}

It should be noted that currently each of the above mentioned methods of studying language disciplines is to some extent effective, as it gives students (applicants) every reason to learn the language properly. However, studies have revealed that the result of learning a foreign language from the application of a particular method (including innovative methods) is different.

In this situation, it should be emphasized that the efficiency of use of methods in learning language disciplines also depends on the knowledge, skills and abilities of the teacher (educator) to operate and correctly apply a method in practice.

For instance, a team of scientists have conducted a survey of students (higher education applicants) in order to determine their position, which are currently the most effective methods of learning a foreign language. Students were asked to determine the efficiency level of each of the methods of learning a foreign language on a scale from " 0 " to "5" points, where a score of " 5 " points indicated a fairly high efficiency of the method (Belyaeva, Samorodova, Voron \& Zakirova, 2019).

According to the results of students' survey, Belyaeva et al. (2019) have come to conclusion that the most effective methods, in addition to innovative ones, which received the highest marks according to the positions of students are as follows: the method of discussion ( $75 \%$ of surveyed students noted this method as the most effective), the method of information and communication technologies ( $74 \%$ of surveyed students noted that it is one of the most effective methods) and the round table method (58\% of surveyed students noted that this method has a positive effect on the result of learning a foreign language). In turn, the less effective methods, from the students' viewpoint are as follows: the role-based method (68\% of the students surveyed expressed a positive position concerning this method) and the business game method (66\% of the students surveyed noted this method to be an effective one). At the same time, the following methods have the low efficiency level, which affects the low level of acquired knowledge in the context of learning a foreign language, namely: method of cooperative learning (64\% of surveyed students expressed the position concerning this method), method of dilemmas (joint discussion) (55\% of surveyed students expressed the position concerning this method), teamwork method (72\% of students surveyed expressed the position concerning this method), extensive reading method (68\% of surveyed students noted this method as one of the most ineffective in learning a foreign language), method of content learning (64\% of students surveyed say that this method is also one of the most ineffective in in learning language disciplines), method of studying in educational firms (58\% of students surveyed expressed their position about the ineffectiveness of this method).

The report of Council of European Union (2018) "Accompanying the document Proposal for a Council Recommendation on a comprehensive approach to the teaching and learning of languages" notes that the practice of 
learning language disciplines is based on innovative methods in the countries of European Union. In particular, the following ones are quite common, namely: 1) the method of translation, which is applied to use different languages in the framework of learning and communication; 2) the method of meaningful and language integrated learning; 3 ) the method of using digital technologies; 4) the method of using creative objects.

Additionally, as part of the disclosure of the subject matter of the academic paper, it would be worth considering the dynamics of changes in the number of students, in particular to conduct a specific analysis of the state and level of foreign language proficiency in Ukraine and abroad (for example, European Union).

Taking into consideration that the dynamics analysis of the average number of foreign languages studied per student by the level of senior secondary education has revealed a high level command of foreign language learning in such countries of European Union as Luxembourg, Romania and Finland, where these indicators both in 2015 and in 2017 did not change, but they remained the highest ones among other countries of European Union, seen to the Figure 1. At the same time, the lowest indicators of the number of languages studied are present in Greece, Denmark, Spain, Germany and Portugal, with a slight increase in 2017 versus 2015, which took place only in Greece and Spain. In addition to these countries, in 2017, compared to 2015, the increase in the number of foreign languages studied per student was observed only in Belgium. On the other hand, there was a decrease of indicators in other European Union's countries, where the highest indicators were observed in Estonia, Cyprus and Malta.

For example, EF Education First (2020), the international educational company, which specializes in language training and study trips, annually conducts the Global Ranking of Countries and Regions for English language proficiency with the determination of the corresponding EF English Proficiency Index; herewith, the number of countries, being assessed, increases every year. This rating shows the differences of citizens' proficiency in English among countries, where this language is not an official one. Classification of countries in the Global ranking of countries and regions is carried out on a following scale: Very High Level, High Level, Moderate Level, Low Level, Very LowLevel. 


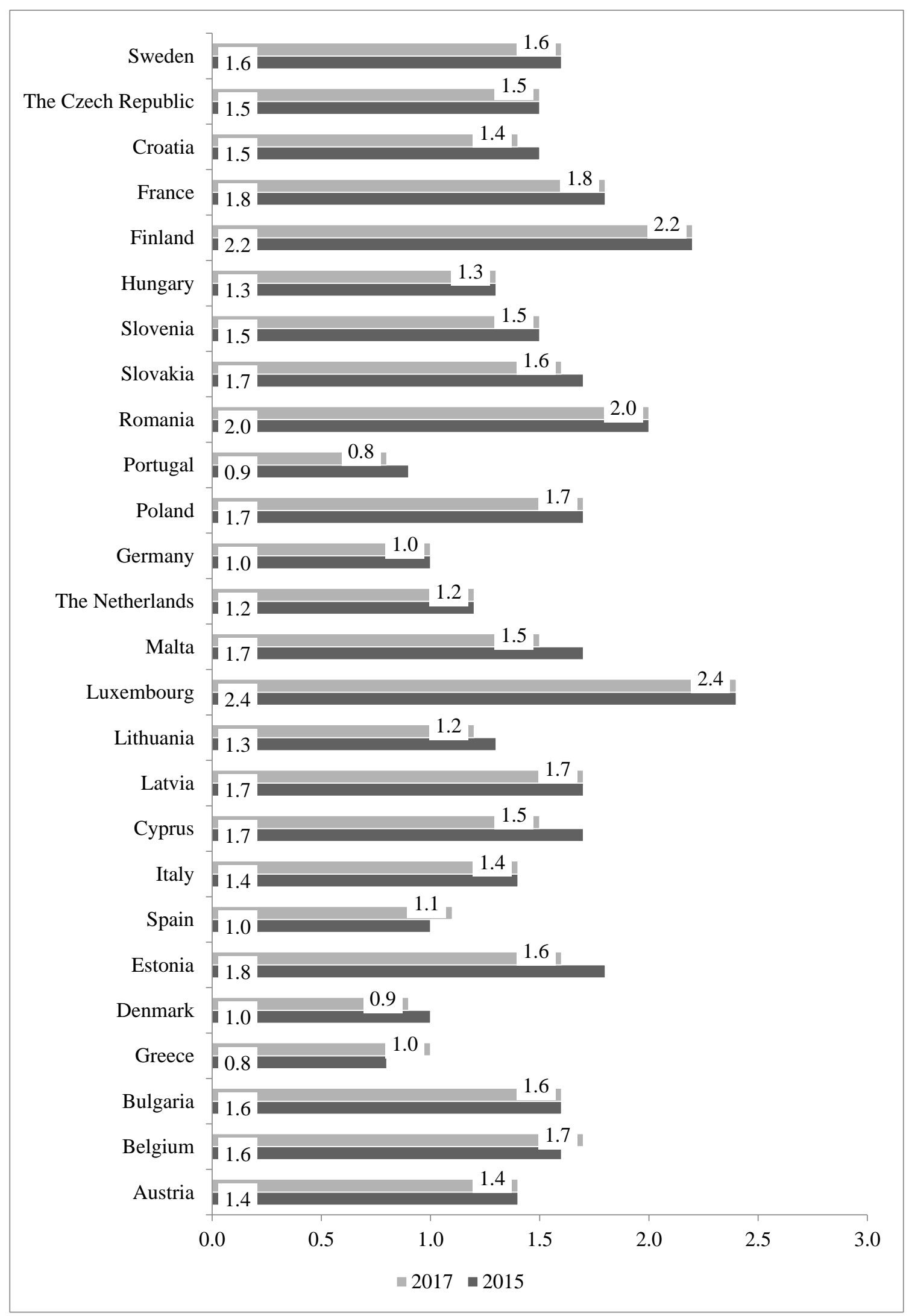

Figure 1. Average number of foreign languages studied per pupil (student) by the level of senior secondary education Source: Eurostat (2019) 
Thus, during 2015-2019, the leading positions in the ranking were occupied by such countries as the Netherlands, Sweden and Denmark; these countries were assigned to those with a very high level of the English language command (Table 1). In addition to the countries mentioned above, Finland, Luxembourg, Austria and Belgium also belong to the category of countries with a high level of the English language command. According to 2019 data, as well as, based on the 2015-2018 ratings, such countries of European Union, as Hungary, Romania, Lithuania, Bulgaria, Slovakia, and Estonia are highly developed ones.As for countries with a moderate level of development, France, Latvia, Spain and Italy should be noted in this list. At the same time, none of European Union Member States, submitted to the Global Ranking of Countries and Regions, during the analyzed period were included in the list of countries with a low and very low level of English proficiency. As contrasted with European Union Member States, the position of Ukraine in the ranking is assigned to countries with a low level of English language proficiency (according to data of 2019, 2017 and 2016) and a moderate level of English language command (according to data of 2018 and 2015).

Table 1. Rating of the countries of European Union and Ukraine on English language proficiency according to Global Ranking of Countries and Regions

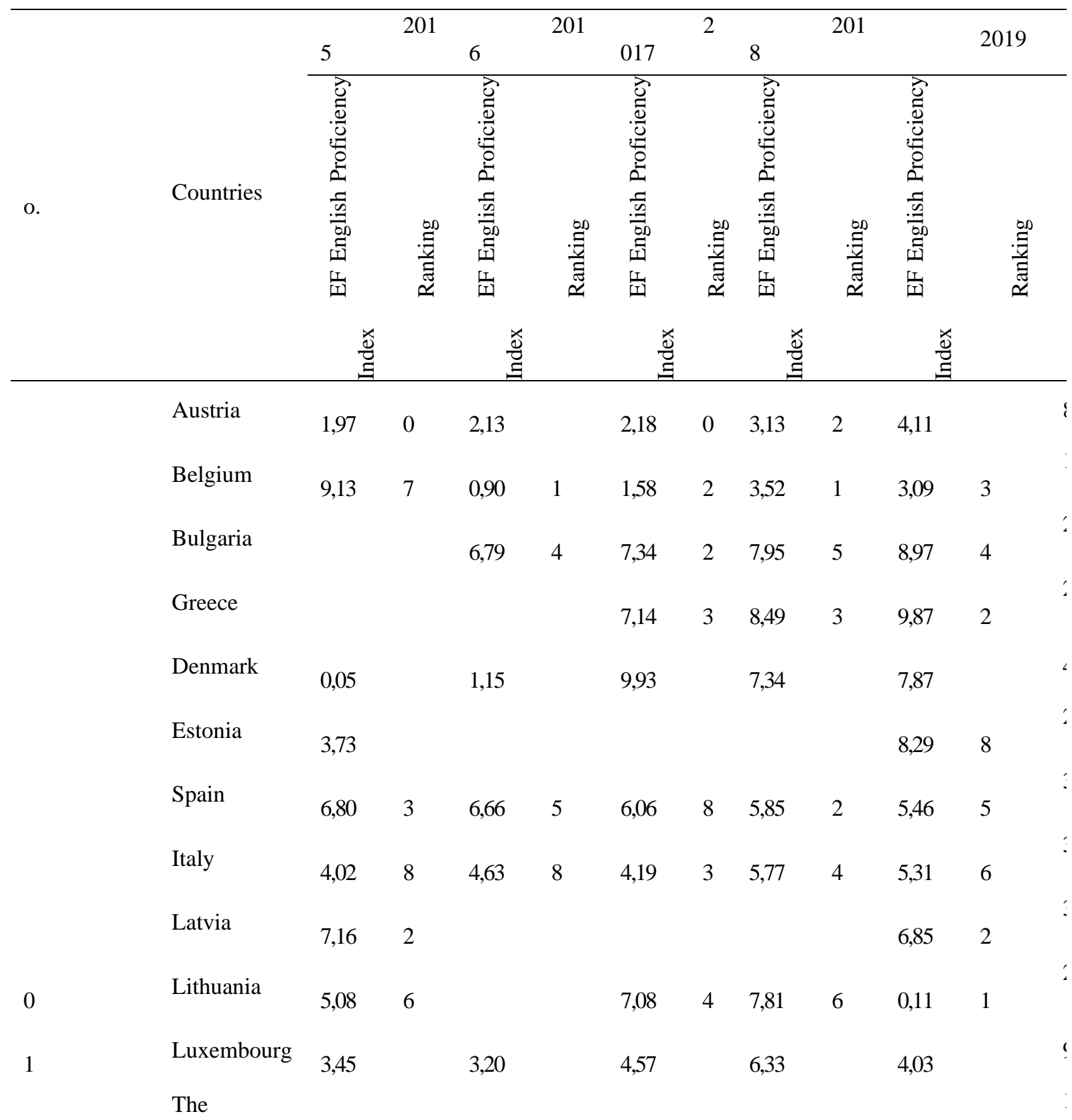




\begin{tabular}{|c|c|c|c|c|c|c|c|c|c|c|c|c|}
\hline 2 & Netherlands & 0,58 & & 2,16 & & 1,45 & & 0,31 & & 0,27 & & \\
\hline 3 & Germany & 1,83 & 1 & 1,58 & & 2,35 & & 3,74 & 0 & 3,77 & 0 & \\
\hline 4 & Poland & 2,95 & & 1,49 & 0 & 2,07 & 1 & 2,45 & 3 & 3,76 & 1 & \\
\hline 5 & Portugal & 0,61 & 3 & 9,68 & 5 & 8,76 & 8 & 0,02 & 9 & 3,14 & 2 & \\
\hline 6 & Romania & 9,69 & 6 & 8,14 & 0 & 9,13 & 7 & 0,31 & 6 & 1,36 & 6 & \\
\hline 7 & Slovakia & 6,34 & 5 & 7,34 & 1 & 7,63 & 1 & 8,11 & 4 & 8,82 & 5 & \\
\hline 8 & Slovenia & 4,97 & & & & & & 4,84 & & & & \\
\hline 9 & Hungary & 7,90 & 1 & 8,72 & 8 & 8,61 & 9 & 9,51 & 1 & 1,86 & 5 & \\
\hline 0 & Finland & 5,32 & & 6,61 & & 5,83 & & 5,86 & & 5,34 & & \\
\hline 1 & France & 1,84 & 7 & 4,33 & 9 & 4,39 & 2 & 5,49 & 5 & 7,25 & 1 & \\
\hline 2 & Croatia & & & & & & & 0,16 & 7 & 3,07 & 4 & \\
\hline 3 & $\begin{array}{l}\text { The Czech } \\
\text { Renublic }\end{array}$ & 901 & 8 & 909 & 6 & 787 & 0 & 999 & 0 & 930 & 3 & \\
\hline 4 & Sweden & 0,94 & & 0,81 & & 0,40 & & 0,72 & & 8,74 & & \\
\hline 5 & Ukraine & 2,61 & 4 & 0,62 & 1 & 0,91 & 7 & 2,86 & 3 & 2,13 & 9 & \\
\hline
\end{tabular}

Source: EF Education First (2020)

An analysis of the provisions of the Western European Recommendations on Language Education makes it possible to identify six levels of foreign language proficiency, a detailed presentation of which is shown in Figure 2: A1 (BeginnerLevel); A2 (ElementaryLevel); B1 (Intermediate Level); B2 (Upper Intermediate Level); C1 (Advanced Level); C2 (Proficient Level). 


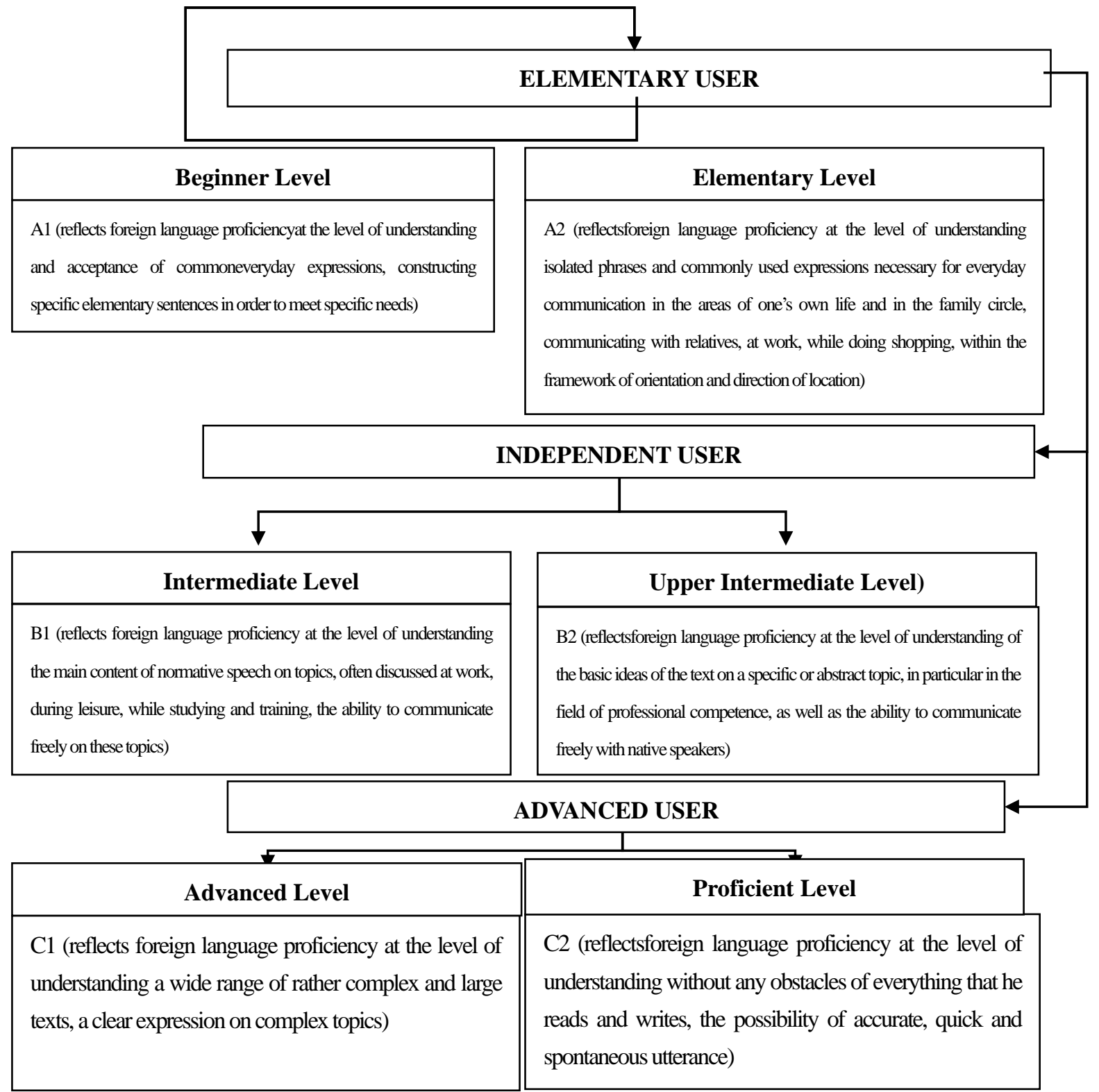

Figure 2.Global Scale of Foreign Languages Levels Proficiency

Source: Nikolajeva (2003)

According to the New Ukrainian School Concept, established by the Ministry of Education and Science of Ukraine, specialized (profile) secondary education in Ukraine should be considered as education obtained at the lyceum or vocational education institutions (duration of receiving profile secondary education is three years). The key areas of profile education that can be selected by the senior school student include: 1) academic direction (where there is an in-depth study of certain subjects, focused on the continuation of their study at the higher educational institutions; 2) professional direction (where the opportunity to obtain the first profession is provided through the acquisition of a complete general secondary education, but this does not impede the continuation of education (The Ministry of Education and Science of Ukraine, 2016).

\section{Discussion}

An analysis of pedagogical practice makes it possible to note that today, the appropriate methods and approaches, properly selected by the teachers, are essential in the system of studying language disciplines, in particular foreign languages during profile training implementation.Herewith, special attention, based on both theoretical analysis of 
the peculiarities of teaching language disciplines during profile training implementation, and the experience of teachers, relies precisely on the use of innovative methods.

The results of the study, presented in the report of Council of European Union (2018) "Accompanying the document Proposal for a Council Recommendation on a comprehensive approach to teaching and learning of languages" make it possible to note that language learning practices in European Union are based on innovative methods, namely: 1) the method of translation, which is applied to use different languages in the framework of learning and communication; 2) the method of meaningful and language integrated learning; 3) the method of using digital technologies; 4) the method of using creative objects.

At the same time, the analysis of the practical experience of applying innovative methods in language disciplines during profile training implementation showed significantly high levels of foreign language proficiency in such countries of European Union, as Luxembourg, Romania and Finland; however, such levels of language command were significantly low in Greece, Denmark, Spain, Germany and Portugal.

For the matter of the position of Ukraine, for example, in the Global Ranking of Countries and Regions, Ukraine is classified as a country with a low level of English proficiency (according to data of 2019, 2017 and 2016) and a moderate level of English proficiency (according to data of 2018 and 2015). It should also be noted that none of the European Union Member States in the Global Ranking of Countries and Regions during the analyzed period were included in the list of countries with low and very low level of English proficiency.

Despite the empirical results of research, it is difficult to answer the questions about the most effective method of teaching. In some cases foreign language teachers refuse to use even innovative methods and the teaching course may not meet the needs of students. Researchers and teachers spend a lot of time proving the effectiveness of innovative methods. An additional factor of effectiveness is the diversity of goals and motives: "the goals and purpose for learning the target language may be different for many language learners" (Vega, 2018).

Innovative methods often require technological requirements for their use (Abduhalykova, 2016), so there are some shortcomings and undesirable effects that need to be addressed. Technological factors determine to some extent the level of efficiency. "The education process can be personalized through ICT" (Kostolanyova \& Nedbalova, 2017).

The preparation of teachers for adaptation to changes in the learning environment and professional skills (Belyaeva et al., 2019) is a consequence of the integration of innovative methods. This can lead to opposition to disruptive innovations: innovations usually face protests against their integration in the first stage of changings.

Another issue of innovative methods in language disciplines concerns the effectiveness of teachers and students. For example, "In students' opinion, the most effective methods of teaching foreign languages are the following: discussion, ICT, and SCRUM", while teachers consider the most effective "discussion, ICT, and round table" (Belyaeva et al., 2019). Our study confirms the effectiveness of ICT, discussion, seminar or brainstorming; a game, project, team game; creative and interactive tasks into the educational process.

Innovations in foreign language teaching depend on such factors as "relative advantage, compatibility, complexity, trialability, and observability" (Carless, 2012). So, the first stage of their integration is the assessment and planning of future benefits, efficiencies and changes. Nowadays, a little bit has been studied about the issues of these changes. Are changes irreversible in the case of integration of innovative methods in foreign language teaching? Identified factors of innovation in the teaching of language determine the level of their acceptance by the subjects of the educational process. This confirms the idea of adherence to the basic principles in the case of integration of innovations (Kostolanyova \& Nedbalova, 2017).

\section{Conclusion}

The results of a study of the theoretical and practical aspects of the application of innovative methods in language disciplines during profile training implementation give grounds to establish the following kinds of innovative methods that are currently used by teachers in language disciplines during profile training implementation, namely: 1) the use of information and computer technology in the process of language learning; 2) the application of developmental methods in the form of dialogue, discussion, seminar or brainstorming; 3)the construction of the educational process in the form of a game, project, team game; 4) the introduction of creative and interactive tasks into the educational process, etc.

In the course of the study, it has been established that each of the above mentioned methods of learning language disciplines is to a certain extent effective, forasmush as it gives the students every reason to learn the language 
properly. However, studies have revealed that the result of learning a foreign language from the application of a particular method (including innovative methods) is different.

The results of the generalization of the survey conducted in the context of studying the position of students regarding the effectiveness of methods (including innovative ones) in order to master a foreign language have showed that the most effective methods, in addition to innovative, which have received the highest marks according to students' positions are as follows; the method of discussions, the method of information and communication technologies and the round table method. In turn, from students' viewpoint, the role-based method and the method of business game are less effective ones. At the same time, such methods, as: the method of cooperative learning, the method of dilemmas (joint discussion), the method of teamwork, the method of extensive reading, the method of content learning, the method of studying in educational firms, have low efficiency level, which affects the low level of acquired knowledge in the context of learning a foreign language.

\section{References}

Abduhalykova, A. M. (2016). Innovative methods of foreign languages teaching. Indian Journal of Science and Technology, 9(22), 1-7. https://doi.org/10.17485/ijst/2016/v9i22/95561

Alimova, X. (2018). Innovative approaches in the technique of teaching foreign languages. Obrazovatelnyj protsess, $1(3), 5-8$.

Belyaeva, I. G., Samorodova, E. A., Voron, O. V., \& Zakirova, E. S. (2019). Analysis of innovative methods' effectiveness in teaching foreign languages for special purposes used for the formation of future specialists' professional competences. Education Sciences, 9, 171. https://doi.org/10.3390/educsci9030171

Bojko, A. (2010). Tutoring as a means of meeting the educational needs of the individual, country and society. Pedagogical Sciences, 1, 4-11.

Bolibekova, M. M., Jalolova, Sh. M., Nematov, O. N., \& Tangriyev, V. A. (2020). The importance of modern methods and technologies in learning English. Journal of critical reviews, 7(6), 143-148. https://doi.org/10.31838/jcr.07.06.28

Carless, D. (2012). Innovation in language teaching and learning. Retrieved from https://doi.org/10.1002/9781405198431.wbeal0540Retrieved https://doi.org/10.1002/9781405198431.wbeal0540

Council of European Union. (2018). Commission staff working document: Proposal for a council recommendation on a comprehensive approach to the teaching and learning of languages. Retrieved from http://data.consilium.europa.eu/doc/document/ST-9229-2018-ADD-2/EN/pdf

EF Education First. (2020). The world's largest ranking of countries and regions by English skills. Retrieved from https://www.ef.com/wwen/epi/

Eurostat. (2019). Foreign language learning statistics. Retrieved from https://ec.europa.eu/eurostat/

Ghorpinich, T. I. (2015). Language portfolio as a means of self-control in learning a foreign language. Scientific Bulletin of Uzhhorod University. Series: Pedagogy, 37, 37-40.

Hodovanets, N. I. (2014). Application of a direct method of teaching a foreign language. Scientific Bulletin of Uzhhorod University. Series: Pedagogy. Social Work, 32, 57-59.

Idrisalieva, L. S. (2019). Innovative methods of teaching foreign languages in non-philologigal universities. Scientific Bulletin of Namangan State University, 1(6), 478-482.

Jakymenko, P. (2019). Formation of technological readiness of future foreign language teachers for specialized training of high school students by means of innovative technologies. Scientific Bulletin of V. O. Sukhomlynskyi Mykolaiv National University. Pedagogical Sciences, 4(67), 263-266.

Kotenko, O. V. (2012). To the problems of formation of professionally significant qualities of the future foreign language teacher. Image of the Modern Pedagogue, 10(119). 62-64.

Kotenko, O. V., \& Holovatenko, T. Yu. (2020). Models of foreign language primary school teacher training in the EU. Innovative Scientific Researches: European Development Trends and Regional Aspect, 5, 92-114. https://doi.org/10.30525/978-9934-588-38-9-5 
Kostolanyova, K., \& Nedbalova, S. (2017). Individualization of foreign language teaching through adaptive e-learning. International Journal of Distance Education Technologies, 15(2), 1-17. https://doi.org/10.4018/IJDET.2017040101

Kozhukhar, O., \& Matviienko, I. (2020). Technological context of foreign language teaching in the professional development of the future specialist. International multidisciplinary scientific journal "Logos", 10, 76-78. https://doi.org/10.36074/2617-7064.10.015

Kuzjmychova, O. O. (2014). Innovative approaches to teaching Ukrainian language and literature in a modern school in the context of specialized education. Taurian Bulletin of Education, 1-2(45), 35-41.

Liu, Q.-X., \& Shi, J.-F. (2007). An analysis of language teaching approaches and methods - Effectiveness and weakness. US-China Education Review, 4(1), 69-71.

Nikolajeva, S. Ju. (Ed.). (2003). Pan-European recommendations for language education: study, teaching, assessment. Kyiv: Lenvit.

Palamar, S. P., Vaskivska, H. O., \& Porjadchenko, L. A. (2019). Psycholinguistic aspects of forming a culture of dialogic communication. Psycholinguistics. Series: Philology, 26(2), 11-26. https://doi.org/10.31470/2309-1797-2019-26-2-11-26

Polonsjka, T. K. (2014). Profile foreign language teaching of high school students (pp. 80). Kyiv: Pedaghoghichna dumka.

Redjko, V. Gh., \& Pasichnyk, O. S. (2012). Features of constructing the content of level learning of foreign languages in the senior profile school of Ukraine. Problems of a Modern Textbook, 12, 649-662.

Rozhkova, N. (2014). The use of information and computer technology as an innovative method in teaching foreign languages. Academic Commentaries. Series: Pedagogical Sciences, 132, 121-125.

The Ministry of Education and Science of Ukraine. (2016). New ukrainian school. Retrieved from https://mon.gov.ua/ua/tag/nova-ukrainska-shkola

Vega, O. (2018). An analysis of the most common methods used to teach English as a second and foreign language. Mextesol Journal, 42(3). Retrieved from https://mextesol.net/journal/index.php?page=journal\&id_article=3777

Vyselko, A. D. (2012). Ways to introduce foreign language immersion in learning English for professional purposes. Scientific proceedings of Ostroh Academy National University. "Philology" Series, 30, 267-170.

Zhalilova, L. Zh. (2018). Implementation of innovative techniques in foreign language teaching. Molodyi vchenyi, 9(195), 156-159. 